\title{
Colorectal surgery in Italy during the Covid19 outbreak: a survey from the iCral study group
}

\author{
Marco Caricato ${ }^{1}$. Gian Luca Baiocchi ${ }^{2} \cdot$ Francesco Crafa $^{3}$. Stefano Scabini ${ }^{4} \cdot$ Giuseppe Brisinda $^{5}$. \\ Marco Clementi ${ }^{6}$. Giuseppe Sica ${ }^{7}$. Paolo Delrio ${ }^{8}$. Graziano Longo ${ }^{9}$. Gabriele Anania ${ }^{10}$. Nicolò de Manzini ${ }^{11}$. \\ Pietro Amodio ${ }^{12}$. Andrea Lucchi ${ }^{13}$. Gianandrea Baldazzi ${ }^{14}$. Gianluca Garulli ${ }^{15}$. Alberto Patriti ${ }^{16}$. Felice Pirozzi ${ }^{17}$. \\ Maurizio Pavanello ${ }^{18}$. Alessandro Carrara ${ }^{19}$. Roberto Campagnacci ${ }^{20} \cdot$ Andrea Liverani $^{21} \cdot$ Andrea Muratore $^{22}$. \\ Walter Siquini ${ }^{23}$ - Raffaele De Luca ${ }^{24}$. Stefano Mancini ${ }^{25}$. Felice Borghi ${ }^{26}$ - Mariantonietta Di Cosmo ${ }^{27}$. \\ Roberto Persiani ${ }^{28}$. Corrado Pedrazzani ${ }^{29} \cdot$ Matteo Scaramuzzi $^{30} \cdot$ Marco Scatizzi $^{31} \cdot$ Nereo Vettoretto $^{32}$. \\ Mauro Totis ${ }^{33} \cdot$ Andrea Gennai $^{34}$. Pierluigi Marini ${ }^{35} \cdot$ Massimo Basti $^{36} \cdot$ Massimo Viola $^{37}$. Giacomo Ruffo ${ }^{38}$. \\ Marco Catarci ${ }^{39}$. The Italian Colorectal Anastomotic Leakage (iCral) study group
}

Received: 1 April 2020 / Accepted: 3 April 2020 / Published online: 20 May 2020

(C) Italian Society of Surgery (SIC) 2020

\begin{abstract}
Background The COVID19 pandemic had a deep impact on healthcare facilities in Italy, with profound reorganization of surgical activities. The Italian ColoRectal Anastomotic Leakage (iCral) study group collecting 43 Italian surgical centers experienced in colorectal surgery from multiple regions performed a quick survey to make a snapshot of the current situation. Methods A 25-items questionnaire was sent to the 43 principal investigators of the iCral study group, with questions regarding qualitative and quantitative aspects of the surgical activity before and after the COVID19 outbreak.

Results Two-thirds of the centers were involved in the treatment of COVID19 cases. Intensive care units (ICU) beds were partially or totally reallocated for the treatment of COVID19 cases in 72\% of the hospitals. Elective colorectal surgery for malignancy was stopped or delayed in nearly $30 \%$ of the centers, with less than $20 \%$ of them still scheduling elective colorectal resections for frail and comorbid patients needing postoperative ICU care. A significant reduction of the number of colorectal resections during the time span from January to March 2020 was recorded, with significant delay in treatment in more than $50 \%$ of the centers.

Discussion Our survey confirms that COVID19 outbreak is severely affecting the activity of colorectal surgery centers participating to iCral study group. This could impact the activity of surgical centers for many months after the end of the emergency.
\end{abstract}

Keywords Colorectal surgery $\cdot$ Covid19 outbreak

\section{Background}

The COVID-19 emergency was declared a WHO pandemic, following the sudden spread in over 160 countries around the world. After an initial diffusion in China, Italy represents one of the most affected countries, with more than 90,000 cases at March 28, 2020 (Fig. 1). This health emergency, as we all know, forced governmental agencies to adopt

Study group coordinator: Marco Catarci.

Marco Catarci

marco.catarci@sanita.marche.it

Extended author information available on the last page of the article restrictive measures to contain the infection. All this has led to an inevitable reorganization of healthcare facilities, with consequent modification of daily clinical and surgical activity. In this scenario, various international surgical societies constantly update the indications on how to adapt the surgical activity on current conditions, and some Italian investigators have already published their experience and the consequent suggestions [1-4].

The Italian ColoRectal Anastomotic Leakage (iCral) study group joins Italian surgeons with special interest in colorectal surgery; it was based initially on 19 surgical centers, having been able to prospectively collect data on 2,717 consecutive colorectal resections performed in 


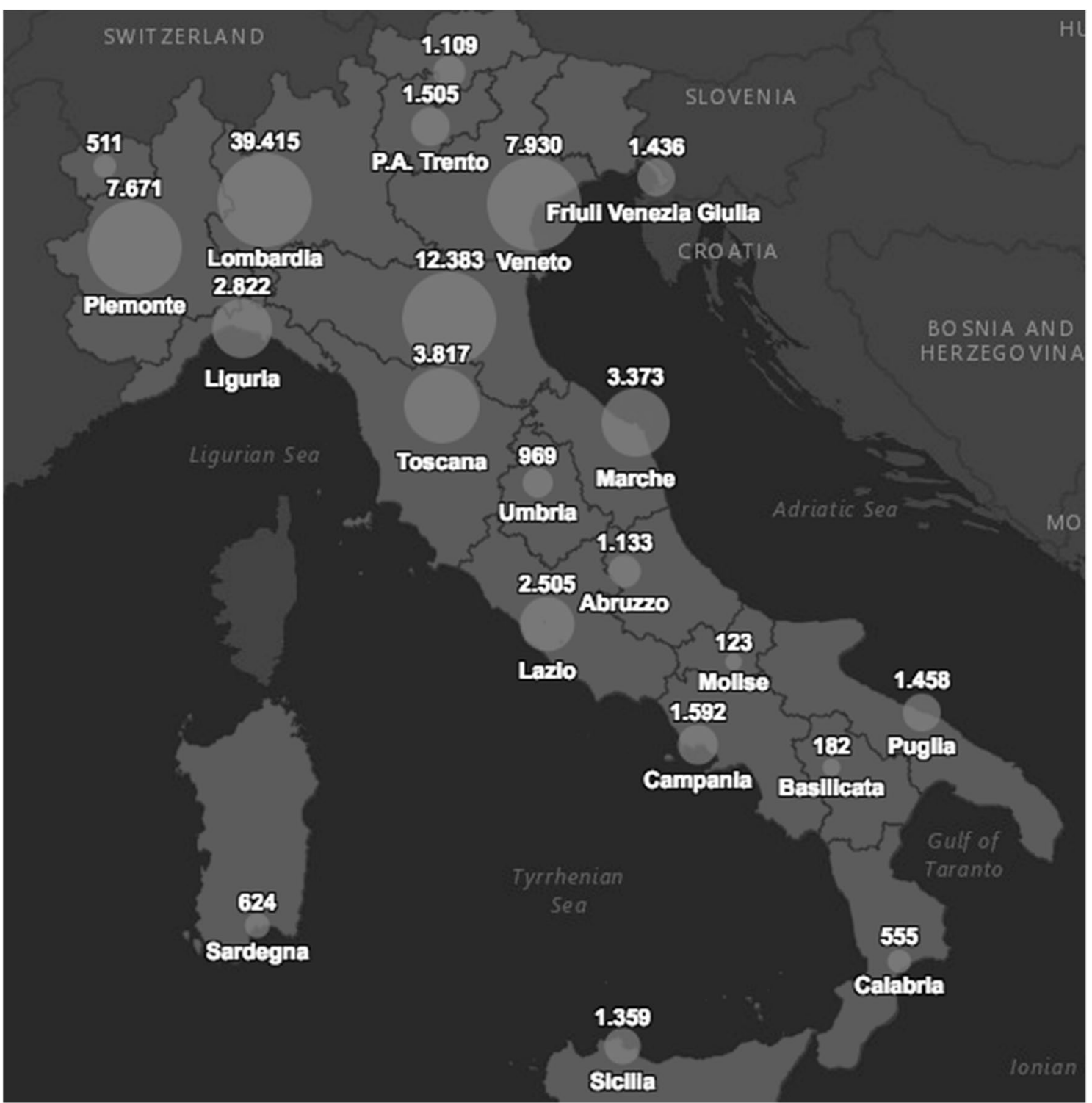

Fig. 1 Number of cases of SARS-CoV-2 infection detected in Italy on March 28, 2020, per region ( source: Dipartimento Protezione Civile, available at: https://opendatadpc.maps.arcgis.com/apps/opsda

one year during its first prospective observational study [5-7]; it has expanded now to 43 centers covering nearly all Italian regions, involved in the ongoing second prospective observational study designed to evaluate the impact of enhanced recovery pathways on early outcomes [Anastomotic Leakage and Enhanced Recovery Pathways After Colorectal Surgery (iCral2); ClinicalTrials.gov NCT03771456]. It represents, therefore, an ideal background for a survey aimed to show a snapshot of the current situation in Italy, and our country represents a model of great interest for many countries with similar socialhealth organization. shboard/index.html\#/b0c68bce2cce478eaac82fe38d4138b1, Accessed March 28, 2020)

\section{Methods}

A 25 -items questionnaire was sent to the 43 principal investigators of the iCral study group, with questions regarding qualitative aspects of surgical activity during the COVID19 outbreak. At March 27, 2020, 39 complete responses were received (compliance 90.7\%). The details of the responding centers are reported in Table 1 . Moreover, data on the number of colorectal resections performed by each center in the time-span from January to March 27, 2020 were gathered from the online database of the ongoing prospective study of the iCral study 
Table 1 Details of the participating centers

\begin{tabular}{|c|c|c|c|}
\hline Variable & Pattern & $N$ & $\%$ \\
\hline \multirow[t]{14}{*}{ Region } & Abruzzo & 2 & 5.1 \\
\hline & Calabria & 1 & 2.6 \\
\hline & Campania & 3 & 7.7 \\
\hline & Emilia Romagna & 3 & 7.7 \\
\hline & Friuli Venezia Giulia & 1 & 2.6 \\
\hline & Lazio & 8 & 20.5 \\
\hline & Liguria & 2 & 5.1 \\
\hline & Lombardia & 4 & 10.3 \\
\hline & Marche & 4 & 10.3 \\
\hline & Piemonte & 2 & 5.1 \\
\hline & Puglia & 3 & 7.7 \\
\hline & Toscana & 1 & 2.6 \\
\hline & Trentino & 1 & 2.6 \\
\hline & Veneto & 4 & 7.9 \\
\hline \multirow[t]{4}{*}{ Hospital type } & Private non academic & 4 & 10.3 \\
\hline & Public non academic & 25 & 64.1 \\
\hline & Private academic & 2 & 5.1 \\
\hline & Public academic & 8 & 20.5 \\
\hline \multirow[t]{4}{*}{ No. of total beds } & $50-200$ & 4 & 10.3 \\
\hline & $201-500$ & 17 & 43.6 \\
\hline & $501-1000$ & 13 & 33.3 \\
\hline & $>1000$ & 5 & 12.8 \\
\hline \multirow[t]{4}{*}{ No. of ICU beds } & $<10$ & 14 & 35.9 \\
\hline & $11-20$ & 12 & 30.8 \\
\hline & $21-30$ & 8 & 20.5 \\
\hline & $>30$ & 5 & 12.8 \\
\hline \multirow{3}{*}{$\begin{array}{l}\text { No. of colorectal resec- } \\
\text { tions in } 2019\end{array}$} & $<50$ & 2 & 5.1 \\
\hline & $51-80$ & 6 & 15.4 \\
\hline & $>80$ & 31 & 79.5 \\
\hline
\end{tabular}

group and analyzed testing the time-trend differences with Kruskal-Wallis variance analysis.

\section{Results}

Two-thirds of the hospitals (26 out of 39) are admitting SARS-CoV-2 (COV2) positive cases, all in separate areas/ buildings of the hospital (Table 2). Quantitative analysis of the time span from January to March 27, 2020 showed a significant reduction of elective colorectal resections (Table 3 and Fig. 2). The waiting time between diagnosis and surgical treatment of colorectal malignancies was significantly delayed in $21(52.5 \%)$ centers (Table 2$)$. Concerning technical details of colorectal resections, 5 centers $(12.5 \%)$ declared performing terminal or diverting stomas more than usual and 8 of them (20.0\%) shifted towards open rather than minimally invasive techniques. Use of enhanced personal protection equipment (PPE) (anything more than standard surgical mask, gown and gloves) was adopted routinely in 5 (12.8\%), only in known and/or suspected COV2+ cases in $22(56.4 \%)$ and never in $12(30.8 \%)$ centers. Only $15(37.5 \%)$ centers declared having adopted some strategies for surgical smoke/pneumoperitoneum filtering/evacuation during minimally invasive procedures.

\section{Discussion}

Few weeks after the outbreak of the COVID19 pandemic, it became clear in Italian hospitals that pulmonology, infectious diseases, internal medicine and intensive care units would suffer the main consequences of a dramatic and sudden epidemiological change. General surgery units have been affected as well by a drastic change in daily procedures. Main issues that affect surgical care are represented by the need to save resources requested for the treatment of actual and expected patients with COV2 infection, and to develop adequate measures to prevent the spread of the disease in patient as well as healthcare professionals. These aspects are severely impacting the treatment of COV2, as well as non-COV2 patients, and the daily activity of surgical teams. Even the request for surgical treatment underwent deep changes: access to health care services decreased as a direct consequence of strict regulations reducing people mobility and crowding; many patients spontaneously postponed both consultations and already scheduled diagnostic and therapeutic procedures.

Surgical departments of the affected areas first reacted on the basis of common sense; however, in the following weeks, many scientific societies developed behavior guidelines for surgical patients care. Among them, major Italian surgical societies developed a joint guidance [8] for surgical practice during this pandemic. All these guidelines and recommendations share the same common baseline: they are based on low level evidences published mostly before the outbreak and point out a precautionary approach due to the lack of any strong scientific evidence. A common advice in such guidelines is to postpone as long as possible elective surgery, based on two reasons: the necessity/opportunity to reallocate as many health resources as possible to the management of COV2 + patients and the observation that unexpected and severe complications and related mortality, even in elective cases [1], have been reported, possibly related to the onset of severe infection in the perioperative period. It is established that COV2 infection has a high lethality in comorbid conditions, and patients in the postoperative phase could be a subgroup in which COVID19 may have a high lethality rate [9]. Thus, in case of urgent and mandatory elective interventions [10], it will be necessary to remodel the therapeutic pathways in the light of the changed resources (in particular the very low availability of intensive care beds). 
Table 2 Results of the survey

\begin{tabular}{|c|c|c|c|}
\hline Question & Answers & $N$ & $\%$ \\
\hline \multirow{2}{*}{$\begin{array}{l}\text { Is your hospital admitting SARS- } \\
\text { CoV-2+ patients }\end{array}$} & Yes & 27 & 69.2 \\
\hline & No & 12 & 30.8 \\
\hline \multirow{2}{*}{$\begin{array}{l}\text { ICU beds partially or totally real- } \\
\text { located for SARS-CoV-2+ cases }\end{array}$} & Yes & 28 & 71.8 \\
\hline & No & 11 & 18.2 \\
\hline \multirow{2}{*}{$\begin{array}{l}\text { Were surgical procedures } \\
\text { performed on SARS-CoV2+ } \\
\text { patients }\end{array}$} & Yes & 13 & 33.3 \\
\hline & No & 26 & 66.6 \\
\hline \multirow{3}{*}{$\begin{array}{l}\text { Which was the indication for sur- } \\
\text { gery on SARS-CoV-2+ patients }\end{array}$} & Time-dependent urgency ${ }^{\mathrm{b}}$ & 9 & 60.0 \\
\hline & Other urgency ${ }^{\mathrm{c}}$ & 3 & 20.0 \\
\hline & Elective surgery for malignancy & 3 & 20.0 \\
\hline \multirow{2}{*}{$\begin{array}{l}\text { Which approach was used for sur- } \\
\text { gery on SARS-CoV-2+ patients }\end{array}$} & Open & 10 & 62.5 \\
\hline & Laparoscopic & 6 & 37.5 \\
\hline \multirow[t]{3}{*}{$\begin{array}{l}\text { Strategies for coping with the } \\
\text { COVID19 outbreak were }\end{array}$} & $\begin{array}{l}\text { Shared with hospital management } \\
\text { and/or local health authorities }\end{array}$ & 18 & 40.9 \\
\hline & $\begin{array}{l}\text { Imposed by hospital management } \\
\text { and/or local health authorities }\end{array}$ & 21 & 47.7 \\
\hline & Self-determined & 5 & 11.4 \\
\hline \multirow[t]{3}{*}{ The number of staff surgeon was } & Unchanged & 32 & 82.0 \\
\hline & Reduced & 6 & 15.4 \\
\hline & Increased & 1 & 2.6 \\
\hline \multirow{2}{*}{$\begin{array}{l}\text { Was any surgeon moved to care of } \\
\text { COVID19 cases }\end{array}$} & Yes & 16 & 41.0 \\
\hline & No & 23 & 59.0 \\
\hline \multirow{2}{*}{$\begin{array}{l}\text { Was there any work plan change } \\
\text { to reduce the exposition to } \\
\text { SARS-CoV-2 }\end{array}$} & Yes & 25 & 64.1 \\
\hline & No & 14 & 35.9 \\
\hline \multirow{2}{*}{$\begin{array}{l}\text { Any staff surgeon infected by } \\
\text { SARS-CoV-2 }\end{array}$} & Yes & 5 & 12.8 \\
\hline & No & 34 & 87.2 \\
\hline \multirow{3}{*}{$\begin{array}{l}\text { SARS-CoV-2 viral screening for } \\
\text { health care workers }\end{array}$} & Routinely & 1 & 2.6 \\
\hline & Symptomatic only & 34 & 87.2 \\
\hline & Never & 4 & 10.2 \\
\hline \multirow{3}{*}{$\begin{array}{l}\text { SARS-CoV-2 viral screening for } \\
\text { surgical candidates }\end{array}$} & Routinely & 3 & 7.7 \\
\hline & Symptomatic only & 31 & 79.4 \\
\hline & Never & 5 & 12.8 \\
\hline \multirow{3}{*}{$\begin{array}{l}\text { Enhanced PPE (anything more } \\
\text { than standard surgical mask, } \\
\text { gown and gloves) }\end{array}$} & Routinely & 7 & 17.9 \\
\hline & $\begin{array}{l}\text { Known or suspected SARS- } \\
\text { CoV-2+ cases }\end{array}$ & 22 & 56.4 \\
\hline & Never & 10 & 25.7 \\
\hline \multirow{2}{*}{$\begin{array}{l}\text { PPE shortage (unavailable and/or } \\
\text { inadequate) }\end{array}$} & Yes & 7 & 17.9 \\
\hline & No & 32 & 82.1 \\
\hline \multirow{3}{*}{$\begin{array}{l}\text { Multidisciplinary board meetings } \\
\text { for colorectal malignancies }\end{array}$} & Unchanged & 8 & 20.5 \\
\hline & Web-based & 17 & 43.6 \\
\hline & Suspended & 14 & 35.9 \\
\hline \multirow[t]{3}{*}{ Digestive endoscopy availability } & Unchanged & 8 & 20.5 \\
\hline & Limited to urgencies & 24 & 61.5 \\
\hline & Limited to emergencies & 7 & 28.0 \\
\hline \multirow{2}{*}{$\begin{array}{l}\text { Are elective colorectal resections } \\
\text { for malignancy being performed }\end{array}$} & Yes & 28 & 71.8 \\
\hline & No & 11 & 28.2 \\
\hline \multirow{2}{*}{$\begin{array}{l}\text { Are elective colorectal resec- } \\
\text { tions for benign disease being } \\
\text { performed }\end{array}$} & Yes & 3 & 7.7 \\
\hline & No & 36 & 92.3 \\
\hline
\end{tabular}


Table 2 (continued)

\begin{tabular}{|c|c|c|c|}
\hline Question & Answers & $N$ & $\%$ \\
\hline \multirow{4}{*}{$\begin{array}{l}\text { Management of frail/comorbid } \\
\text { cases with anticipated need of } \\
\text { postoperative ICU }\end{array}$} & Unchanged & 8 & 20.5 \\
\hline & Referring to another center & 3 & 7.7 \\
\hline & Suspended & 13 & 33.3 \\
\hline & Unanswered & 15 & 59.0 \\
\hline \multirow{4}{*}{$\begin{array}{l}\text { Time from diagnosis to surgery } \\
\text { for colorectal malignancy before } \\
\text { COVID-19 outbreak }\end{array}$} & $<14$ days & 5 & 12.8 \\
\hline & 15-30 days & 28 & 71.8 \\
\hline & 31-45 days & 5 & 12.8 \\
\hline & $>45$ days & 1 & 2.6 \\
\hline \multirow{4}{*}{$\begin{array}{l}\text { Time from diagnosis to surgery } \\
\text { for colorectal malignancy dur- } \\
\text { ing COVID-19 outbreak }\end{array}$} & $<14$ days & 3 & 7.7 \\
\hline & 15-30 days & 11 & 18.2 \\
\hline & 31-45 days & 19 & 48.7 \\
\hline & $>45$ days & 6 & 15.4 \\
\hline \multirow{2}{*}{$\begin{array}{l}\text { Are you performing more termi- } \\
\text { nal and/or derivative stomas } \\
\text { than usual }\end{array}$} & Yes & 5 & 12.8 \\
\hline & No & 34 & 87.2 \\
\hline \multirow{2}{*}{$\begin{array}{l}\text { Are you performing more open } \\
\text { vs laparoscopic approach than } \\
\text { usual }\end{array}$} & Yes & 8 & 20.5 \\
\hline & No & 31 & 79.5 \\
\hline \multirow{2}{*}{$\begin{array}{l}\text { Availability of high-speed devices } \\
\text { for dissection/hemostasis }\end{array}$} & Reduced & 3 & 7.7 \\
\hline & Unchanged & 36 & 92.3 \\
\hline \multirow{2}{*}{$\begin{array}{l}\text { Measures to reduce dispersion } \\
\text { of biological aerosol during } \\
\text { laparoscopy }\end{array}$} & Yes & 14 & 35.9 \\
\hline & No & 25 & 64.1 \\
\hline
\end{tabular}

$P P E$ personal protection equipment

${ }^{\text {a }}$ Multiple answers possible

be.g.: perforation, bowel ischemia, hemorrhage, vascular occlusion

${ }^{c}$ e.g.: appendicitis, cholecystitis, bowel obstruction

Table 3 Number of colorectal resections performed from January to March 27, 2020 in surgical centers participating to iCral study group prospective observational study [Anastomotic Leakage and Enhanced
Recovery Pathways After Colorectal Surgery (iCral2); ClinicalTrials. gov NCT03771456]

\begin{tabular}{|c|c|c|c|c|c|c|}
\hline \multirow[t]{2}{*}{ Period } & \multirow[t]{2}{*}{ Overall $N$} & \multicolumn{5}{|c|}{ Single center } \\
\hline & & Mean \pm SD & Median & $95 \% \mathrm{CI}$ & Range & $p^{* *}$ \\
\hline January 2020 & 507 & $12.8 \pm 7.1$ & 12 & $10.5-15.1$ & $3-43$ & 0.0076 \\
\hline February 2020 & 468 & $11.8 \pm 7.5$ & 9 & $9.3-14.2$ & $3-42$ & \\
\hline March 2020 & 353 & $8.8 \pm 7.8$ & 6 & $6.2-11.4$ & $0-35$ & \\
\hline
\end{tabular}

**January-February $p=0.06$; February-March $p=0.0253$; January-March $p=0.0022$

Another major issue is the possible diffusion of the infection related to the surgical procedure, in patients with confirmed, suspected or possible COV2 infection. The recent experience on Coronavirus outbreak raised the evidence that non-symptomatic patients can efficiently spread the virus, as reported in Germany [11]. It is documented also that the virus has tropism even for non-respiratory mucosal surfaces such as the conjunctiva [12]. The high prevalence of infected patients, mostly asymptomatic, and the limited possibility to perform sensitive diagnostic tests makes every surgical procedure at risk of viral spreading. As a matter of fact, in two out of three elective colorectal resections performed on COV2+ patients in this survey (Table 2) the diagnosis of viral infection through RT-PCR analysis on naso-pharyngeal swabs was obtained in the 
Fig. 2 Number of colorectal resections per single iCral center performed in 2020 (data up to March 27, 2020); $p=0.0076$

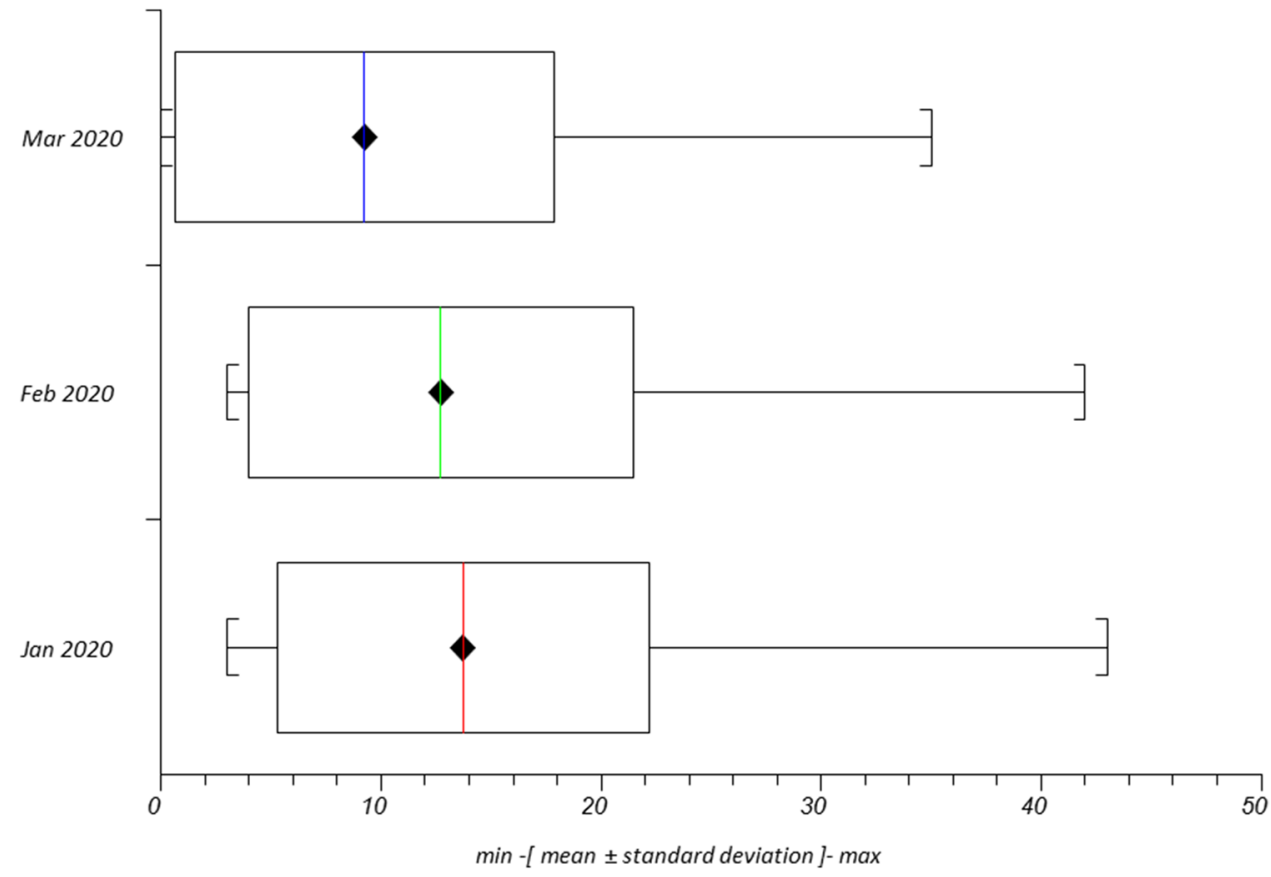

postoperative period due to the onset of unexplained postoperative fever.

It is well demonstrated that surgical procedures entailing the use of electrocautery and/or high-speed devices for dissection/hemostasis generate aerosol spreading beyond the sterile area $[13,14]$, and that this aerosol can harbor viruses [15]. Very few papers studied the contamination linked to laparoscopic approach [16], without identifying recommended risk-reducing procedures. Even clear and evidence-based reports concerning the clinical efficacy of facemasks [17] are lacking, entailing a great variety, sometimes conflicting, of guidelines, recommendations and policies, pointing out the need for further research in this area. Current guidelines for the protection of health care workers in the operating room are somewhat conflicting: they go from nothing more than standard surgical protection [18] to the use of N95 respirators or respirators that offer a higher level of protection [19]. According to the US National Institute for Occupational Safety and Health (NIOSH) classification of particulate filtering facepiece respirators, N95 respirators are not resistant to oil with a filtering efficiency of $95 \%$. The European Standard (EN 149:2001) classification divides particulate filtering facepiece respirators into three classes: FFP1, FFP2, and FFP3 with corresponding minimum filtration efficiencies of $80 \%, 94 \%$, and $99 \%$. Therefore, FFP2 and N95 respirators can be considered equivalent [20], making them recommended for use in the prevention of airborne infectious diseases in the US and other countries.

In absence of preoperative testing for any patient undergoing surgery, most of the published recommendations state that the protection of health care workers should be at the highest level for all surgical cases [1], assuming that any patient could be an asymptomatic carrier of the virus, while taking into account also logistic feasibility, hospital and community limitations, facility resources and patients' needs.

Within the iCral study group, we confirmed the deep impact of the COVID19 outbreak on surgical practice. Our survey confirms that a high percentage of the centers have been affected by the epidemic: although only $15.5 \%$ of the surgical units had a reduction in staff, the staff was partially reallocated to non-surgical services in $40 \%$ of the remaining. The change in allocation of resources had a great impact on the volume of activity: 1 out of 3 centers reduced the colorectal cancer surgery volume, although less than 1 out of 5 continues operating fragile patients with possible need for postoperative intensive care. The average number of cases operated, however, has significantly reduced, and in about half of the centers the waiting times have lengthened. Although no recommendation about changes in surgical techniques was made, some centers declared an increase of the use of terminal or diverting stomas, probably aiming at minimizing the need for post-operative intensive care and possible system overload consequent to the management of anastomotic leakage. All these factors have a severe impact on the treatment of non-COV2 cases: we must therefore prepare for the prioritization of cases and we can expect an increase of late diagnosis of patients with colorectal cancer. We can expect an increase of workload for the treatment of non-urgent diseases after the resolution of pandemic, but also an increase of urgent cases due to non-electively treated cases of benign diseases. Therefore, the impact on therapeutic pathways can be expected to continue for a long time. 
It seems evident from epidemiological data, and confirmed by our survey, that protection of patients and OR personnel is not adequately addressed. Hospitals are an unsafe place due to the concentration of people, and healthcare personnel are severely affected by the epidemic, with more than 6000 infected health care workers and over 50 deaths among medical doctors to date in Italy. At 75 days from the first information about of epidemic in China (January 9) and 35 (February 21) in Italy, viral screening is performed routinely on patients in 3 hospitals and on health care workers in one hospital only; $10 \%$ of our hospitals never perform RT-PCR test on surgical candidates. Severe shortage of PPE is reported only in a strict minority of the hospitals, nevertheless, a routine change of behavior related to the prevention of spread has not been adopted: routine use of enhanced PPE is limited to a small minority of cases, strategies for evacuation of smokes and pneumoperitoneum are used in less than half of hospitals, a reduction in the use of laparoscopy is reported in $20 \%$ of centers.

\section{Conclusion}

Our survey confirms that COVID19 outbreak is severely affecting the activity of colorectal surgery centers participating to iCral study group. The pattern of modifications of the volume of activity are quite uniform through the country, irrespectively of the fact that COV2 surgical cases occurred or not. The treatment of urgent and oncological cases is warranted in most Centers, with some limitations. The workload is reduced for multiple reasons, included the reduction of diagnostic procedures. This could impact the activity of surgical centers for many months after the end of the emergency.

The major concern revealed by the survey is the great heterogeneity of the preventive measures against the spread of the disease among patients and health care workers. Clear guidelines are still lacking, while the stricter recommendations are being generally unapplied due to underestimation of the infectious risk of surgical procedures and to the shortage of PPE.

The lesson learned in this critical context should drive health care professionals to a better awareness of the risks related to surgical care, to design clear guidelines for prevention of spread of viral infection in surgical environment, to establish the routine use of best practices for reducing microbiological risk in surgical care.

Funding This research received no specific grant from any funding agency in the public, commercial or not-for-profit sectors. Medtronic SI ${ }^{\circledR}$ Italy gave liberal and unconditioned logistic support for several investigator meetings, held in Milan, Italy, on September 2017 and June 2018, in Rome, Italy, on October 2018, in Matera, Italy, on June 2019 and in Bologna, Italy, on October 2019.

\section{Compliance with ethical standards}

Conflict of interest The authors declare that they have no conflict of interest.

Research involving human participants and/or animals All procedures performed in studies involving human participants were in accordance with the ethical standards of the institutional and/or national research committee and with the 1964 Helsinki declaration and its later amendments or comparable ethical standards.

Informed consent For this type of study formal consent is not required.

\section{References}

1. Spinelli A, Pellino G (2020) COVID-19 pandemic: perspectives on an unfolding crisis. Br J Surg. https://doi.org/10.1002/ bjs.11627(epub ahead of print)

2. Zucco L, Levy N, Ketchandji D, Aziz M, Ramachandran SK, Anesthesia Patient Safety Foundation. Perioperative Considerations for the 2019 Novel Coronavirus (COVID-19). https:// www.apsf.org/news-updates/perioperative-considerations-forthe-2019-novel-coronavirus-covid-19/, Accessed 12 Feb 2020

3. SAGES recommendations in light of the COVID-19 pandemic. https://www.sages.org/recommendations-surgical-responsecovid-19/, Accessed 27 Mar 2020

4. Coccolini F, Perrone G, Chiarugi M, Catena F et al (2020) Surgery in COVID-19 patients: operational directives. World J Em Surg (in press)

5. The Italian ColoRectal Anastomotic Leakage (iCral) Study Group (2020) Anastomotic leakage after elective colorectal surgery: a prospective multicentre observational study on use of the Dutch leakage score, serum procalcitonin and serum C-reactive protein for diagnosis. BJS Open. https://doi.org/10.1002/ bjs5.50269 (epub ahead of print)

6. The Italian ColoRectal Anastomotic Leakage (iCral) study group (2019) Colorectal surgery in Italy: a snapshot from the iCral study group. Updates Surg 71:339-347

7. The Italian ColoRectal Anastomotic Leakage (iCral) study group (2020) Risk factors for adverse events after elective colorectal surgery: beware of blood transfusions. Updates Surg. https://doi.org/10.1007/s13304-020-00753-2(in press)

8. ACOI-SIC Intercollegiate General Surgery Guidance on COVID-19, issued on March 30, 2020. https://www.acoi.it/00_ newsletter/20200330_Covid-19_Acoi_Sic.pdf. Accessed 31 Mar 2020

9. Brindle M, Gawande A (2020) Managing COVID-19 in surgical systems. Ann Surg. https://doi.org/10.1097/SLA.0000000000 003923

10. Yu GY, Lou Z, Zhang W (2020) Several suggestions of operation for colorectal cancer under the outbreak of corona virus disease 2019 in China. Zhonghua Wei Chang Wai Ke Za Zhi 23:208-211. https://doi.org/10.3760/cma.j.cn.441530-20200 224-00074

11. Rothe C, Schunk M, Sothmann P et al (2020) Transmission of 2019-nCoV infection from an asymptomatic contact in Germany. N Eng1 J Med 382:970-971. https://doi.org/10.1056/ NEJMc2001468

12. Chang XuH, Rebaza A, Sharma L, Dela Cruz CS (2020) Protecting health-care workers from subclinical coronavirus infection. Lancet Respir Med 8(3):e13. https://doi.org/10.1016/S2213 -2600(20)30066-7 (epub 2020 Feb 13) 
13. Brat Ga, Hersey SP, Chhabra K, Gupta A, Scott J (2020) Protecting teams during the COVID-19 outbreak: a narrative review and clinical considerations. Ann Surg. https://journals.lww. com/annalsofsurgery/Documents/COVID\%20Surgery_VF.pdf. Accessed 28 Mar 2020.

14. Farmer WM, Nataupsky M Gorochovskaya R (1994) Identification of aerosol production during surgical procedures 00229128; NIOSH. https://www.cdc.gov/niosh/nioshtic-2/00229128.html, Accessed 28 Mar 2020.

15. Kwak HD, Kim SH, Seo YS, Song KJ (2016) Detecting hepatitis B virus in surgical smoke emitted during laparoscopic surgery. Occup Environ Med 73:857-863

16. Englehardt RK, Nowak BM, Seger MV, Duperier FD (2014) Contamination resulting from aerosolized fluid during laparoscopic surgery. JSLS 18(e2014):00361. https://doi.org/10.4293/ JSLS.2014.00361

17. MacIntyre CR, Chughtai AA (2015) Facemasks for the prevention of infection in healthcare and community settings. BMJ 350:h694. https://doi.org/10.1136/bmj.h694
18. The Association of Coloproctology of Great Britain and Ireland. ACPGBI Guidance for Colorectal Surgeons and Trainees on Rising to the Challenges of COVID-19 as Citizens, Doctors and Surgeons. https://www.acpgbi.org.uk/content/uploads/2020/03/ ACPGBI-statement-on-COVID-19.pdf, Accessed 28 Mar 2020

19. American College of Surgeons. COVID-19: Considerations for Optimum Surgeon Protection Before, During, and After Operation. https://www.facs.org/covid-19/clinical-guidance/surgeonprotection. Accessed 28 Mar 2020

20. Lee SA, Hwang DC, Li HY, Tsai CF, Chen CW, Chen JK (2016) Particle size-selective assessment of protection of European Standard FFP respirators and surgical masks against particlestested with human subjects. J Healthc Eng 2016:8572493. https ://doi.org/10.1155/2016/8572493

Publisher's Note Springer Nature remains neutral with regard to jurisdictional claims in published maps and institutional affiliations.

\section{Affiliations}

Marco Caricato ${ }^{1} \cdot$ Gian Luca Baiocchi ${ }^{2} \cdot{\text { Francesco } \text { Crafa }^{3} \cdot \text { Stefano Scabini }}^{4} \cdot$ Giuseppe Brisinda $^{5}$. Marco Clementi ${ }^{6}$. Giuseppe Sica ${ }^{7}$. Paolo Delrio ${ }^{8}$. Graziano Longo ${ }^{9}$. Gabriele Anania ${ }^{10}$ - Nicolò de Manzini ${ }^{11}$. Pietro Amodio ${ }^{12}$. Andrea Lucchi ${ }^{13}$. Gianandrea Baldazzi ${ }^{14}$. Gianluca Garulli ${ }^{15}$. Alberto Patriti ${ }^{16}$. Felice Pirozzi ${ }^{17}$. Maurizio Pavanello ${ }^{18}$. Alessandro Carrara ${ }^{19} \cdot$ Roberto Campagnacci $^{20} \cdot$ Andrea Liverani $^{21}$. Andrea Muratore ${ }^{22}$. Walter Siquini ${ }^{23} \cdot$ Raffaele De Luca $^{24}$ - Stefano Mancini ${ }^{25} \cdot$ Felice Borghi $^{26} \cdot$ Mariantonietta Di Cosmo $^{27}$. Roberto Persiani ${ }^{28}$. Corrado Pedrazzani ${ }^{29}$. Matteo Scaramuzzi ${ }^{30} \cdot$ Marco Scatizzi $^{31}$. Nereo Vettoretto ${ }^{32}$. Mauro Totis $^{33}$. Andrea Gennai ${ }^{34}$. Pierluigi Marini ${ }^{35}$. Massimo Basti ${ }^{36}$. Massimo Viola ${ }^{37}$. Giacomo Ruffo ${ }^{38}$. Marco Catarci ${ }^{39}$ (1) . The Italian Colorectal Anastomotic Leakage (iCral) study group

1 Colorectal Surgery Unit, Campus BioMedico University Hospital, Rome, Italy

2 General Surgery Unit 3, University and Spedali Civili, Brescia, Italy

3 General and Oncologic Surgery Unit, Moscati Hospital, Avellino, Italy

4 General and Oncologic Surgery Unit, National Cancer Center "San Martino", Genoa, Italy

5 General Surgery Unit, San Giovanni di Dio Hospital, Crotone, Italy

6 General Surgery Unit, University Hospital, L'Aquila, Italy

7 General Surgery Unit, Tor Vergata University Hospital, Rome, Italy

8 Colorectal Surgical Oncology Unit, IRCCS G. Pascale Foundation, Naples, Italy

9 General Surgery Unit, Policlinico Casilino, Rome, Italy

10 General Surgery Unit, University Hospital, Ferrara, Italy

11 General Surgery Unit, University Hospital, Trieste, Italy

12 General Surgery Unit, Belcolle Hospital, Viterbo, Italy

13 General Surgery Unit, Ceccarini Hospital, Riccione, RN, Italy

14 General Surgery Unit, ASST Nord Hospital, Sesto San Giovanni, MI, Italy
15 General Surgery Unit, Infermi Hospital, Rimini, Italy

16 General Surgery Unit, Marche Nord Hospital, Pesaro e Fano, PU, Italy

17 General Surgery Unit, ASL Napoli2 Hospital, Pozzuoli, NA, Italy

18 General Surgery Unit, AULSS2 Hospital, Conegliano Veneto, TV, Italy

19 General Surgery Unit, Santa Chiara Hospital, Trento, Italy

20 General Surgery Unit, C. Urbani Hospital, Jesi, AN, Italy

21 General Surgery Unit, Regina Apostolorum Hospital, Albano Laziale, RM, Italy

22 General Surgery Unit, E. Agnelli Hospital, Pinerolo, TO, Italy

23 General Surgery Unit, ASUR AV3 Hospital, Macerata, Italy

24 Surgical Oncology Unit, IRCCS Istituto Tumori Giovanni Paolo II, Bari, Italy

25 General and Oncologic Surgery Unit, San Filippo Neri Hospital, Rome, Italy

26 General Surgery Unit, Santa Croce e Carle Hospital, Cuneo, Italy

27 General Surgery Unit - Upper GI, University Hospital, Verona, Italy

28 General Surgery Unit, Catholic University Hospital, Rome, Italy 
29 General Surgery Unit - Lower GI, University Hospital, Verona, Italy

30 General Surgery Unit, IRCCS Casa Sollievo della Sofferenza, San Giovanni Rotondo, FG, Italy

31 General Surgery Unit, Santa Maria Annunziata Hospital, Firenze, Italy

32 General Surgery Unit, Spedali Civili of Brescia, Montichiari, BS, Italy

33 General Surgery Unit, San Gerardo Hospital, Monza, Italy

34 General Surgery Unit, Sant'Andrea Hospital, La Spezia, Italy
General Surgery Unit, San Camillo Hospital, Roma, Italy

36 General Surgery Unit, Santo Spirito Hospital, Pescara, Italy

37 General Surgery Unit, Cardinale Panico Hospital, Tricase, LE, Italy

38 General Surgery Unit, IRCCS Sacro Cuore Don Calabria Hospital, Negrar di Valpolicella, VR, Italy

39 General Surgery Unit, Ospedale "C. E G. Mazzoni”, ASUR Marche AV5, Via degli Iris snc, 63100 Ascoli Piceno, Italy 